\title{
VITICULTURE IN THE CZECH REPUBLIC: SOME SPATIO-TEMPORAL TRENDS
}

\author{
Ilona SVOBODOVÁ, Antonín VĚŽNÍK, Michael KRÁL
}

\begin{abstract}
From a global perspective, the growing of grapevines in the Czech Republic is of peripheral importance. For a group of grape-growing villages in southern Moravia, however, the making of wine is bound up with local history, traditions and cultural life, and contributes significantly to the local economy. This paper describes the current status of viticulture in Bohemia and Moravia, addressing changes in the number and structure of wine producers and pointing out some qualitative changes that the business is undergoing. Changing consumer tastes have brought a demand for quality wines of local origin, which cannot be met without high quality care of vineyards throughout the lifetime of the vines. Special attention is given to two alternative ways of tending vineyards - the development of integrated production, and organic viticulture - that are developing rapidly in the Czech Republic even when compared to Austria and Germany.
\end{abstract}

\section{Shrnutí}

\section{Vinohradnictví v České republice: prostorově-časové trendy}

Pěstování vinné révy $v$ České republice má sice z hlediska celosvětového spíše okrajový význam, velkou roli však hraje v řadě vinařských obcí preveážně v regionu jižní Moravy, kde je tradičně silně spjato s místní historií, současným kulturním životem a představuje př́nos pro lokální ekonomiku. Předkládaný př́spěvek se zabývá současnou situací $v$ českém, resp. moravském vinohradnictví - pozornost je věnována nejen změnám v počtu a struktuře pěstitelü, ale radě kvalitativních změn, kterými odvětví prochází. Změny ve spotrebitelských návycích obyvatel zvyšují poptávku po kvalitních vínech domácí provenience, jež se neobejdou bez neméně kvalitní péče o vinohrady $v$ průběhu vegetačního období. Pozornost je rovněž věnována rozsahu alternativních zpưsobů hospodaření ve vinicích (rozvoji integrované produkce a ekologickému vinohradnictví), které se i ve srounání s Rakouskem či Německem rozvíjí v ČR velmi dynamicky.

Keywords: viticulture, vine-growers, organic viticulture, integrated production, Czech Republic

\section{Introduction}

Grapes have been grown in Bohemia and Moravia since ancient times, as shown by the first written records from the Great Moravian Empire (ninth century A.D.), as well as by archaeological findings. The planting of vineyards came into its own during the High Middle Ages (eleventh to thirteenth centuries), when large vineyards were planted, the first applicable legal regulations were established, knowledge of viticulture spread among the local populations, and wine trading increased. Throughout their history, viticulture and wine making have undergone frequent cycles of feast and famine, expanding and then declining again. These fluctuations have often been connected with the general political, economic and social environment in the Czech lands. Living conditions influence every farmer. The twentieth century was no exception and vine growers as well as wine makers in Bohemia and Moravia were influenced by many internal and external factors even to the present. There are currently more than 19,000 farmers engaged in viticulture in Bohemia and Moravia, many of whom make their own wine. Especially in southern Moravia, vine growing and wine making are widespread, inseparable parts of the history and cultural life of many villages, and that make significant contributions to the local economy.

The principal objective of this article is to analyse the current situation of the industry from the perspective of the most prominent recent changes. Some trends in the viticulture of neighbouring countries can occur in the Czech Republic as well. Studies already published show changes in consumers' habits, the lifestyles of inhabitants in particular, which, in return, influence the sector of wine production and subsequently growers (e.g. Kraus et al., 1999). The increasing demand for high-quality wines, as well as the availability of a wide range of foreign wines, develops pressures towards high-quality production and care for grapes even during their ripening in vineyards. The growth of vineyard areas in the system of integrated production comprises the most conspicuous tendency influencing Czech grape growers and wine producers. As well, the organically farmed vine area is growing considerably.

The extent to which Czech producers can compare to their foreign competitors will depend not only on the quality of their products (for some consumers, even the term "organic" itself implies high quality), but also on their marketing abilities, emphasising the singular character of some products reflecting local natural conditions, i.e., the phenomenon known as "terroir" in the wine-growing terminology. According to numerous wine makers, wines with a distinctive "terroir" come from grapes grown with a minimum use of synthetic substances (pesticides or fertilizers), emanating from grapes from integrated production and from grapes from organically-farmed vineyards.

\section{Literature review}

According to van Leeuwen (2009), no other agricultural product has such a strong relationship with the soil as wine. The concept of terroir as an interactive ecosystem at a given place, including climate, soil and wine, is poetically expressed by Banks et al. (2007) who claim that "wine is the essence 
of a place in a bottle". Overton, Murray and Banks (2011) assert that what makes a wine unusual or even unique in the world of globalized products, is its close association with its place of origin. The controversial, mystical phenomenon of terroir has a power to explain different prices of wines with similar organoleptic characteristics. It can give competitive advantages in wine marketing (Vaudour, 2002; Corinto, 2011). Chartes (2006) points out that human factors, among different local factors reflected in terroir and influencing the wine, are important as no vineyard exists without the intervention of mankind. According to Gade (2004), the quality of wine depends heavily on local traditions and experience. Vaudour (2002) studied in detail the connection with the above-mentioned idea of terroir and label of origin. From his book, as well as from many of the studies mentioned above, we can conclude that the quality of wine and the knowledge of its origin are often considered to be closely connected. While premium wine is designated by its origin from a specific region (even a specific vineyard), bulk wine has no such designation or interpretative function (Charters, 2006). Finally, Schamel (2006) claims that drinking of especially expensive wine has to do with the knowledge of place.

Lately, in both the traditional wine producing countries (France, Spain, Italy and Portugal), as well as among 'New World' producers (Australia, New Zealand, Argentina, Chile, USA), there are many qualitative changes in the wine sector. Although it is quite difficult to explain them briefly in global terms, for many countries almost all over the world several trends are apparent. One issue is that consumers have started to place more emphasis on preferring the origins of the vine of a particular area, of a growing community, or even the individual farmer. Consumers have also become more demanding and less price-sensitive. This "consumer turn" towards traditional or typical food products (in general, i.e., not only for the case of wine), is also seen in the recent agro-food literature, a summary of which is offered by Barham (2003). On the other hand, it needs to be noted that certain consumers prefer New World wines, which are cheaper and at the same time of a comparable quality to the traditional European wines.

On a global scale, viticulture is described as having experienced a significant shift from a quantitative orientation towards high-quality production (Dougherty, 2003; Jones, 2003; Pitte, 2004; Tomš́́k and Prokeš, 2011). The situation in individual non-European states is analyzed, for example, by Pont (2010) in Argentina, Overton, Murray and Silva (2011) in Chile, and Barker, Lewis and Moran (2001) in New Zealand. At the same time as this "quality turn" has occurred, European countries with a long tradition of viti-/viniculture are gradually losing their quasi-monopoly position in wine producing and exporting, relinquishing their market shares to New World countries, which have emerged as significant players in the global wine market since the late 1980s. Another trend is that wine consumption per capita in the traditional wine-consuming countries is decreasing. According to Pitte (2004), the production of ordinary wines collapsed in the second half of the $20^{\text {th }}$ century - there is no future even for French wines without an orientation to quality and particular geographical character.

Another trend was noted by Goodman (2003, cited in Bouzidine - Chameeva and Krzywoszynska, 2011), who connected the general quality turn in food production with the recent growth of the organic wine sector. Over the last few years, organic wines developed a notable presence on the global wine scene, especially due to many countries of the New World moving rapidly towards organic viticulture (Mueller, Remaud, 2010).

Similar trends to those occurring in the top-ranked wineproducing countries have shaped the wine industry in the Czech Republic. In the 1990s, the Czech agricultural sector experienced important reforms influencing organizational structure and property ownership, when converting collective farms into other corporate or legal structures not based on the collective property. Many former agricultural businesses in the South Moravian region farmed vineyards in tens of hectares as a part of their varied plant production, often without concurrent wine-making. During the process of transformation, new farming businesses emerged. Recently, in correspondence with the global production and consumer trends, they have also started to focus on premium wine production (as a great advantage we can name especially a long tradition of vine growing and wine making in this region). The number of enterprises with vine growing and the related production of wine is increasing. Special wine production such as the production of organic wines, straw wines or ice wines is also flourishing. Currently, it is typical of smaller family wineries rather than large agricultural enterprises.

The issue of changes in viti-/viniculture has also been a subject of much research in the Czech Republic by authors mainly from the disciplines of economics or agriculture (Kraus, 1999; Graffe, 1984 or Jung, 1984, more recently Tomšík and Chládková, 2005; Chládková, Tomšík and Gurská, 2009). For example, topics connected with wine consumption and demand for wines were analyzed by Chládková, Pošvár, Žufan (2004), and Žufan (2004b). A comparison of Czech conditions with some EU countries in the pre-accession period was discussed by Škorpíková (2002), Tomšík, Sedlo (2005), and after the Czech Republic joined the EU by Hicl (2012). Kučerová (2005) points out that the Czech Republic shows a number of particularities in these characteristics when compared to neighbouring Slovakia or Austria, such as the fact that the Czech Republic is a country where beer is strikingly popular. A number of papers have focused on the impact of legislative changes in the area of viticulture in particular related to the Czech Republic's entry into the EU in 2004, which is of major interest to active wine makers. Of recent works, evaluating the situation and development tendencies in Czech viticulture, Koráb (2012) should be cited, as this contribution noticeably aims at the perception of the European Wine Policy by Moravian vinegrowers and winemakers. As is evident from his research, as well as from the other papers mentioned above, the Czech industry of viticulture and viniculture is represented by a colourful range of businesses of various sizes, with varying production experiences and marketing abilities. These businesses differ in their approach to the environment and to the treatment of vineyards, among other factors.

This paper builds on the above-mentioned contributions in many respects, based on available statistical data, summarizing basic development tendencies in Czech viticulture and viniculture. Considerable attention is paid to current trends in environmental factors, which in practice means using alternative ways of farming (integrated production of grapevines, and organic viticulture). Although it is a perspective direction on development according to Hicl (2012), the issue of Czech organic viticulture has not been analyzed to any great extent at this time, except for the work of Hluchý $(2011,2013)$, the chair of the Ekovín 
civic association (association of Czech vine-growers farming organically and integrally) and a prominent world expert for the greening of vine growing.

\section{Methodology and data}

It is necessary to set basic definitions and terms before analyzing quantitative changes in viticulture and wine making/viniculture (number of growers, area farmed). Pursuant to Wine Act No. 321/2004 Coll., the terms used are defined as follows:

- Vine-grower (in Czech conditions) is a person engaged in viticulture in a vineyard, while a vineyard means farmed land of an area larger than 10 ares $^{1}$, continuously planted with grapevine by one grower, who was assigned one or more registration numbers following a written application to the Central Institute for Supervising and Testing in Agriculture (CISTA). A vineyard sized less than 10 ares is a vineyard only if it has a registration number assigned by the institute, based on a written application;

- Viticulture is an industry of vegetable production engaged in growing table varieties of vine (Vitis vinifera), vine grapes meant for direct consumption and must varieties of vine, meant for the production of grape wines;

- Wine making is a sector of the food industry dealing with the processing of vine grapes into grape wines and secondary products;

- A winemaker is a natural or legal person who produces or labels the product to put it into circulation;

- A "small" area vineyard is often referred to in this article as an area smaller than 1 ha - in the conditions of the Czech Republic this is, at the same time, the limit for receiving subsidies (unlike Austria, for example, where it is $0.5 \mathrm{ha}$ ).

The two industries are closely related, many vine-growers also make wines; however, some winemakers do not farm vineyards of their own. This paper deals with the grapegrowing activities of those growers who farm vineyards according to the above-mentioned criteria (attention is not paid to small growers with vineyards which are not registered, i.e. those who produce grapes for winemaking only for their own consumption). A set of data published by the Czech Statistical Office (CSO) can be used to describe the trends in the development of Czech viticulture. The specificity of the processes in the Czech vini- and viticulture can also be determined from comparing the situation of these two industries with neighbouring countries.

It is possible to use the summary reports published by individual Ministries of Agriculture (MoAs) to obtain the information on vine growers (Green Report in the Czech Republic, Green Report in Slovakia, Grüner Bericht in Austria, Agrarpolitischer Bericht in Germany), as well as special thematic reports published by the ministries (annually published Special Report on Vine and Wine by MoA of the Czech Republic), and results from statistical surveys of a global character. In the Czech Republic, data can also be used from the nationwide survey of agribusinesses: "Agrocensus" (usually carried out every ten years - exceptionally in 1995, in 2000 , and in 2010 , when it was already in line with the rules of European Union), and from surveys - the Structure Farm Survey 2007, 2013. Comparing developments in viticulture in the Czech Republic with neighbouring countries (in this paper, the situation in Slovakia, Austria and Germany), brings in similar surveys from these countries - the globallyoriented Farm Structure Census 2010 is obtained from the statistical offices in Germany, Slovakia and Austria.

From a methodological point of view, there is a problem as different thresholds for individual businesses are used for entities to be included in the survey: 1 ha utilised agricultural area (UAA) in Slovakia and in Austria, or 5 ha UAA in Germany and in the Czech Republic. The threshold for including a business according to a vineyard area differs, too: businesses with a minimum vineyard area of 25 ares (under marketable vines) are included in Austria, 35 ares of vineyards in the Czech Republic, 50 ares in Slovakia and in Germany. Although the above censuses provide for a good mutual comparability (e.g. total production volumes in the individual countries), different limits for the censuses do not make comparisons possible, for example in comparing the number of wineries. For topical information about the number of growers, we also use data from vineyards registers operated by the Central Institute for Supervising and Testing Agriculture (CISTA in the Czech Republic) or the Central Controlling and Testing Institute in Agriculture (CCTIA in Slovakia), which cover all vineyards intended for the commercial production of grapes, grape must, wine, or vegetative propagation material for vines. Smaller self-suppliers can be registered too. The obligation of vine growers to register their vineyards can slightly differ from country to country. In the Czech Republic, all vineyards of a minimum area of 10 ares are subject to registration, in Slovakia those with at least 300 grapevine bushes or 50 ares.

The information about the vineyards area, varieties and age is available from the national statistical surveys on viticulture, such as the "Basic Survey of Areas under Vine", which all individual EU member states are obliged to provide at ten-year intervals ("Survey of Vineyards 2009" in the Czech Republic; "Statistical Survey of Vineyards 2009" in Slovakia; "Weingartengrunderhebung 2009" in Austria). Methodologies of data collection slightly differ even in these large-scale surveys: for example, in Austria the survey was outlined as a full survey covering all subjects registered in the vine registry (subjects with at least 0.5 ha of vineyard and also self-suppliers); in the Czech Republic, the survey of subjects with an area from 0.1 ha of vineyard and larger, who produced at least a part of their production for sale; and in Slovakia, the businesses registered in the Business register and Agricultural register of the Statistical Office of the Slovak Republic, which performed the prescribed activity according to the classification of economic activities (NACE) - growing permanent crops 01.2 and propagating plants 01.3 .

Despite the different criteria of classifying businesses in the statistical surveys of the respective countries, it holds true that every country proceeds in their specifications consistently with the knowledge of their structure of farms or vine growers. It is possible to assume that the stated circumstances of a methodological character do not influence the determination of basic processes or directions in development in the vine-growing and winemaking industries across these countries.

Many of the global surveys mentioned above are insufficient to obtain an overview of the alternative ways of farming the vineyards, as they only contain information

11 are $=100 \mathrm{~m}^{2}$ 
about the total size of organically farmed land or arable land. The most comprehensive information on the issue of organic farming in the Czech Republic can be obtained from the "Statistical Survey of Organic Farming", published by the Institute of Agricultural Economics and Information (IAEI) for the Czech Ministry of Agriculture. It is possible to use The List of Organic Farmers published on the web pages of the Ministry of Agriculture of the Czech Republic for a more detailed analysis of regional differences in the location of organic farming or organic viticulture. At the time this article was written, the current data were accessible as of 31 December 2011. The data on the area of organicallyfarmed land, including vineyards in various countries, are collected in Switzerland by the Research Institute of Organic Agriculture (FiBL), cooperating with the International Federation of Organic Agriculture Movements (IFOAM). Contrary to organic farming, for which the data have been collected already for several years and which is very well regulated by international legislation, collecting data on the system of integrated production in a central database is not possible (as the principles are not identical in individual countries). In this paper, we used data presented in the Green Reports of the Czech Republic and Austria, data from the German Wine Institute, and data from the CCTIA, Slovakia.

\section{Results}

\subsection{Development of viticulture in the Czech Republic}

Basic development trends in global viticulture, many of which also affect the Czech growers, are as follows:

- According to the German Wine Institute (DWI, 2013), there was a decrease in the total area of vineyards in the world between 2009 and 2012, and European Union member countries are classified as regions with the highest reductions of vineyard area. The highest absolute decrease in the size of vineyards was recorded in countries with the largest vineyards, a long tradition of viti-/viniculture, and with a strong tradition of wine consumption by the local population. If we compare the years 2012 and 1990, Spain reduced its area of vineyards by $33.6 \%$, France by $14.8 \%$, Italy by $24.9 \%$, Portugal by $36.9 \%$, Greece by $26.7 \%$, and Hungary by as much as $53.6 \%$. On the other hand, a striking growth of vineyard area was observed in that period in the USA China, Chile, Brazil, Australia and Russia;

- A slight decrease in wine consumption is evident in traditional vine-growing countries such as Italy, Spain and France. By contrast, annual consumption of wine in litres per capita is reported by many countries of Central and Western Europe (e.g. Germany, Austria and Great Britain). Chládková, Tomšík, Gurská (2009) state that the popularity and consumption of wine in countries where vine was not that well known have been growing (e.g. Chile, USA);

- The European Union, which used to be the most prominent global exporter of wine for centuries, has been struggling with the growing imports of wine from nonEuropean countries, and wine exports are growing at a slower rate; and

- Wine consumption per capita is also growing slowly in the Czech Republic, but the wine trade is growing (both imports and exports are increasing), and there is growth in the demand for and in sales of quality wine (Chládková, Tomšík, Gurská, 2009).
According to data from the CISTA vineyards register (published by MoA CR, 2013a), the area of vineyards representing the current production potential of the CR is 19,633.45 ha: this consists of areas planted with vine (17,198 ha), and other areas such as grubbed-up vineyards, areas with replanting rights, and those with existing planting rights in reserve. Productive vineyards (older than four years) form an absolute majority of planted areas, and over-mature vineyards (older than 50 years) cover approximately only $2 \%$ of the total vineyards area. The situation when the area of productive vineyards is stabilized can be evaluated positively; as compared to the year 2004, when it was 13 thousand hectares, it has been oscillating around 16 thousand hectares for several years now. In particular this is due to new intensive vineyards planted under the influence of subsidies from the EU in 2001-2004. These were planted with respect to a limited possibility of planting new vineyards after joining the European Union (as compared with the situation as of 1 May 2004, an increase of vineyards area is possible only by $2 \%$ of the area planted at that time, i.e. by additional ca. 385 ha). At present, new vineyards can be planted only as replanted vines (after previous grubbing up or obtaining replanting rights from somebody else).

The vine growing region of Moravia has an absolutely prominent position in terms of regional differentiation in the location of vineyards in the Czech Republic - the largest vineyards are in the district of Břeclav (9,258 ha), Hodonín (3,940 ha), Znojmo (3,040 ha), Brno-Province and Uherské Hradiště. As is evident from the total size of vineyards in districts with the most significant viticulture in Bohemia (Litoměřice - 254 ha, Mělník - 246 ha), vine growing is just a marginal part of the total agricultural production (vineyards do not represent more than $1 \%$ of farmland in any of the vine growing districts in Bohemia). The size of vine regions in Bohemia and Moravia is illustrated in Fig. 1. The representation of vineyards in the farmland of districts in the Czech Republic is evident from Fig. 2.

The vine register data collected by CISTA indicate that the number of registered vine growers in the Czech Republic has been oscillating over the long term around 19 thousand subjects (it was still increasing in the first years of the Czech Republic's EU membership). Most entities farm vineyards in south Moravia and only about 150 of them in Bohemia. Since 2006, a slight decrease in the number of registered entities is visible. As Tab. 1 shows, the number of vine-growers decreased also in neighbouring countries (the decrease in Germany and Austria was recorded over a longer period, and in Germany, the large decrease was slightly influenced by a change in the basis of the survey). When comparing the data from the vineyards register with the results from the survey on vineyards from 2009, it can be concluded that almost one- half of Bohemian and Moravian vine growers accounted for in the register, are solely selfsuppliers farming vineyard areas smaller than 0.1 ha. Farming of such areas has an uncertain future - it is usually a hobby combined with the experience of particular people. It is, however, a matter of tradition in the region of southern Moravia where vineyards and wine cellars are passed on from "a father to his son", and individual families have developed strong emotional ties to them.

In this respect, the situation in the Czech Republic does not differ from other countries, where small vine growers are also represented in considerable numbers. The Czech Republic currently records a similar number of vine-growers 


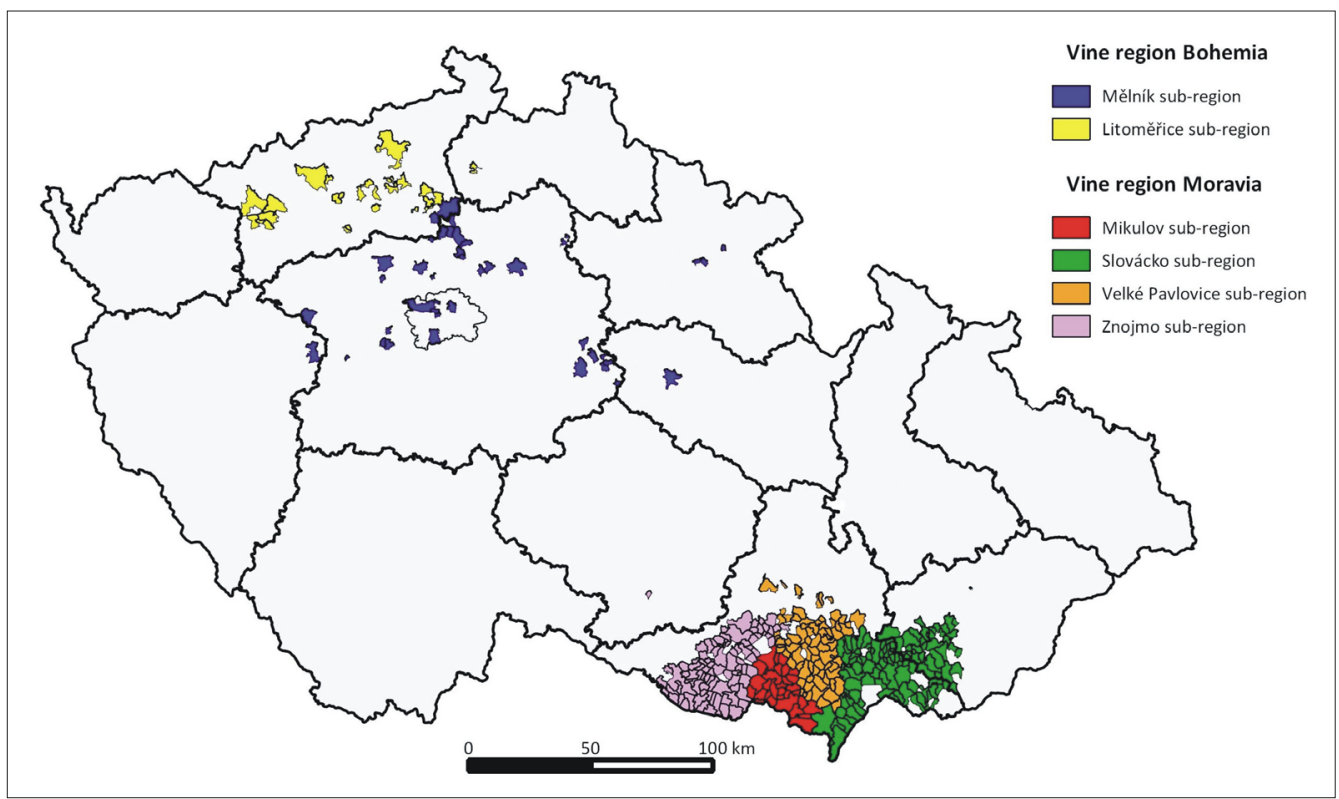

Fig. 1: Vine Regions of the Czech Republic

Source: Ministry of Agriculture of the Czech Republic, 2013

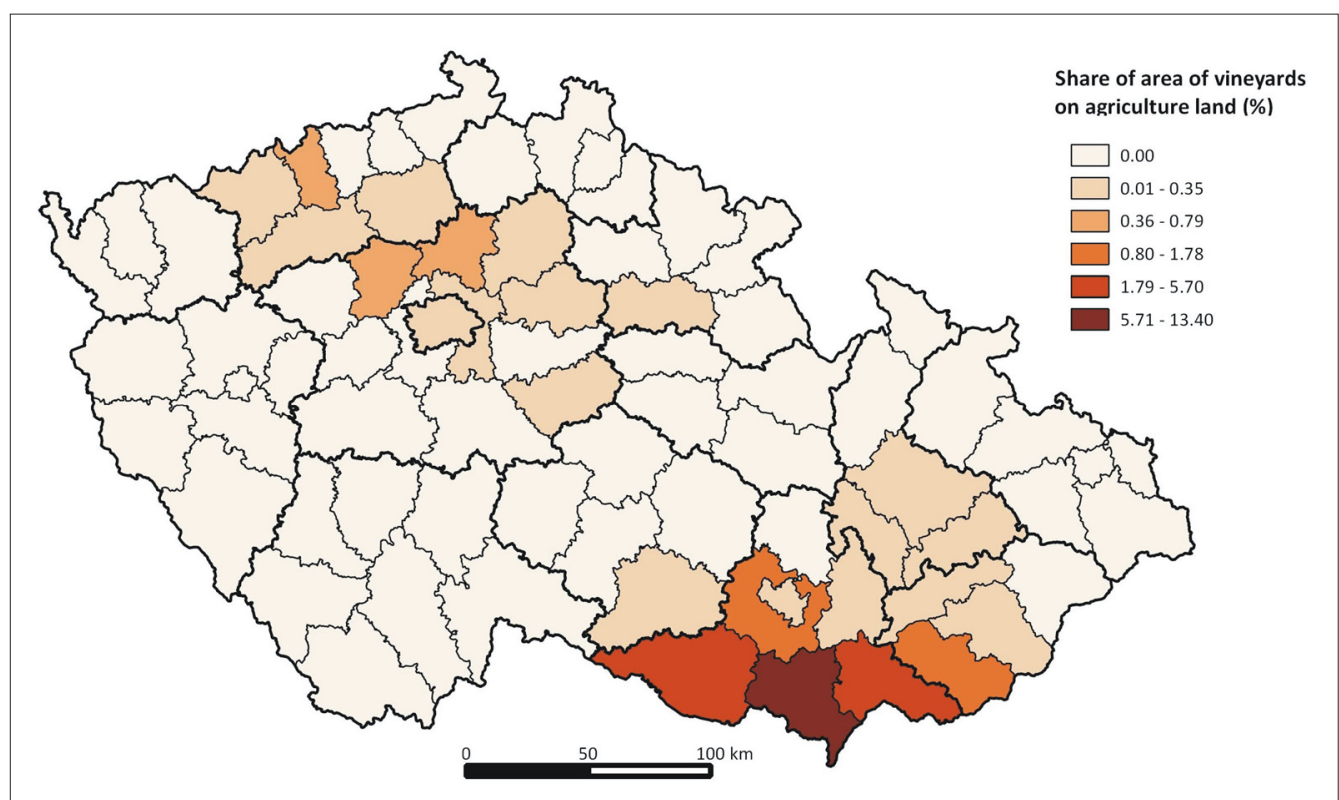

Fig. 2: The area share of vineyards on agricultural land in the Czech Republic in 2012

Source: Czech Office for Surveying, Mapping and Cadastre (COSMC), 2012

\begin{tabular}{|l|c|c|c|c|c|c|c|c|}
\hline & \multicolumn{2}{|c|}{ Czech Republic } & \multicolumn{2}{c|}{ Slovakia } & \multicolumn{2}{c|}{ Austria } & \multicolumn{2}{c|}{ Germany } \\
\cline { 2 - 10 } & 2005 & 2011 & 2005 & 2011 & 2005 & 2011 & 2005 & 2011 \\
\hline Number of vinegrowers $^{1)}$ & 20,394 & 19,037 & $\mathrm{n} / \mathrm{a}$ & 25,000 & $32,044^{2)}$ & $20,181^{3)}$ & 68,603 & 20,290 \\
\hline Vineyards area $^{4}$ (ha) & 18,554 & 17,198 & $\mathrm{n} / \mathrm{a}$ & 22,452 & 45,733 & 43,839 & 98,875 & $97,008^{5)}$ \\
\hline
\end{tabular}

Tab. 1: Number of vine-growers and vineyard area in the CR and in neighbouring countries in 2005 and 2011 Notes: 1) Figures from vineyards registers which include vine-growers with at least 10 ares of vine in the CR, or 30 ares in Slovakia and several vine-growers voluntarily registered with a very little area under vineyards. In addition, those vine-growers are included who do not have to have plant vineyards but have a right of replanting. In Austria, all vine-growers are included questioned in the Basic survey of areas under vine 2009 (full survey), in Germany, vinegrowers with a vineyard area of 30 ares and more according to the Agricultural Structure Survey 2010 (Federal Statistical Office, Germany, 2011); 2) Reference years 1999; 3) Reference year 2009; 4) Includes the area of vine growers registered in the Vineyards Registers of CISTA, CCTIA (CZ, SK), productive vineyards (Austria), data from the German Wine Institute; 5) Reference year 2010. n/a - data not available Sources: CISTA, 2012; Statistics Austria, 2009; German Wine Institute, 2006, 2013 
as the neighbouring Austria which, however, has more than twice the area of vineyards (with the productive vineyards prevailing as well). In Slovakia, the situation is different, since according to the information from the CCTIA, about one-half of the registered vineyard area is not being farmed at all (according to the Farm Structure Census 2010, including businesses of both legal entities and natural persons with a minimum of 0.5 ha of vineyard, represented only by 1,208 subjects farming $11,044.1$ ha of vineyards, i.e. ca. $5 \%$ of the registered entities and less than one-half of the registered vineyards).

Comparing the often hardly comparable data, we can conclude that a greater part of vineyards registered in the Czech Republic is really farmed. Grapes for wine making intended solely for home consumption are grown on a very small proportion of vineyards (roughly $5 \%$ of the area), and a large part of vineyards is farmed by a group of vine growers with over 5 ha of vineyards area (MoA, 2012).

Fig. 3 shows that the largest vineyards according to area farmed (over 100 ha) can be found only in Moravia - they play a considerable role especially in the Znojmo and Hodonín districts, where, regardless of a high number of small growers, these several farms cultivate areas corresponding approximately to one-third of the vineyard areas of individual districts. In the vine growing region of Bohemia, large growers can be found (over 60 ha of vineyard area) only in the districts of Most and Litoměřice. In other districts of Bohemia, small growers prevail completely, both in number and in terms of their share in the total vineyard area.

It is evident from the number and structure of vinegrowers and from the total vineyard area, both in the Czech Republic and in its neighbouring countries, there is a visible tendency for the emergence of larger businesses. Smaller entities disappear due to various reasons: important factors include the low profitability of grape growing, influenced as well by the increasing costs of vine management (viticulture often remains a hobby paid by "putting one's hand into one's pocket"), prices of pesticides and fertilizers are increasing, and the average price of table grapes is lower than before joining the EU, as well as the older ages of the grower, etc. One trend that has been recorded concerns increasing the average vineyard area even where the total area of vineyards is decreasing (from 1.52 ha in 1999 to 2.26 ha in 2009 in Austria).

The districts of southern Moravia traditionally are categorized into regions with the highest number of vinegrowers in the Czech Republic (CISTA, 2012). Small-scale vine-growing, i.e. up to 1 ha of productive vineyard area, is widespread mainly in the Břeclav district $(8,415$ growers in 2012) and the Hodonín district $(7,069)$. In the Znojmo district, there are "only" 744 growers. Villages with the highest numbers of registered vine growers are shown in Tab. 2 (in most of these villages, the number of growers has hardly changed at all from 2004 to 2012).

The popularity of vine-growing and wine-making, the activities of wineries and wine associations in these districts, are indirectly documented in Fig. 4, demonstrating the support of the Wine Growers Fund of the Czech Republic in various promotional events with the theme of wine held in 2013 (fairs and exhibitions of wine, wine tasting, wine festivals, promotion in the form of the creation of publications on wine, etc.). Again, the districts of southern Moravia Břeclav and Hodonín - with a large base of wine traditions among wider groups of the population, predominate in the number of organized events or those supported by the Wine Growers Fund.

As mentioned above, a large proportion of the total vineyard area is held by larger companies (over 5 ha) - very often businesses of legal entities who farm approximately $64 \%$ of the Czech vineyard area (Farm Structure Survey 2010: the survey did not include sole self-suppliers with farmed areas less than 0.35 ha). Apart from the assumed varied size of land farmed, they differ slightly in the representation of growing grapes for the production of quality and table wines (91.1\% of the area intended for growing quality wines by legal persons' enterprises, compared to the share of $80.5 \%$ by natural persons). Compared to legal entities, natural persons generally farm larger areas intended for table grapes production.

The varying degrees of experience with the European Common Agricultural Policy (CAP) can be mentioned as another difference. Large enterprises are almost solely

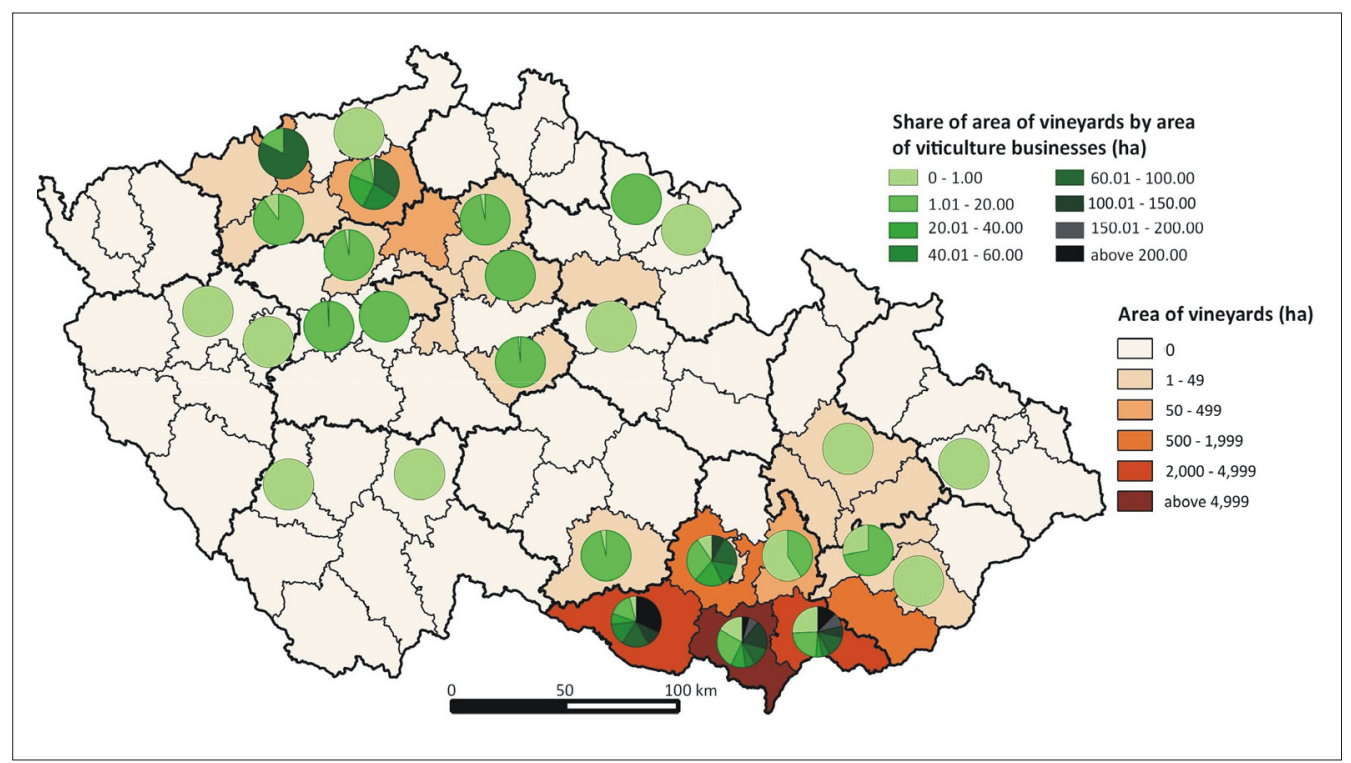

Fig. 3: Structure of viticulture businesses in the Czech Republic in 2013

Sources: CISTA, 2013; COSMC, 2013

Note: Subjects assigned according to their home address or company address 


\begin{tabular}{|l|c|c|c|c|c|}
\hline \multicolumn{1}{|c|}{ Village } & District & $\begin{array}{c}\text { Area of vineyards } \\
\mathbf{2 0 1 2}(\mathbf{h a})\end{array}$ & $\begin{array}{c}\text { Number of vine } \\
\text { growers 2012 }\end{array}$ & $\begin{array}{c}\text { Number of vine } \\
\text { growers 2004 }\end{array}$ & $\begin{array}{c}\text { Index of change } \\
\mathbf{( 2 0 1 2 / 2 0 0 4 ) ( \% )}\end{array}$ \\
\hline Velké Bílovice & Břeclav & 722.7 & 1,011 & 993 & 101.8 \\
\hline Mutěnice & Hodonín & 318.2 & 989 & 1,006 & 98.3 \\
\hline Čejkovice & Hodonín & 521.6 & 710 & 710 & 100.0 \\
\hline Velké Pavlovice & Břeclav & 362.3 & 620 & 579 & 107.1 \\
\hline Kobylí & Břeclav & 273.6 & 516 & 596 & 86.6 \\
\hline Rakvice & Břeclav & 207.6 & 472 & 496 & 95.2 \\
\hline
\end{tabular}

Tab. 2: The largest vine growing villages in the Czech Republic according to the number of vine growers in 2012 Comments: The number of vine growers in a particular village is influenced by a number of factors - not only by the vineyard area itself but also by terrain segmentation, presence of bigger businesses in the structure of vine growers, sizes of land ownership (given e.g. by heritage tradition), specific traditions in a respective region etc.

Source: MoA CR, 2010, $2013 a$

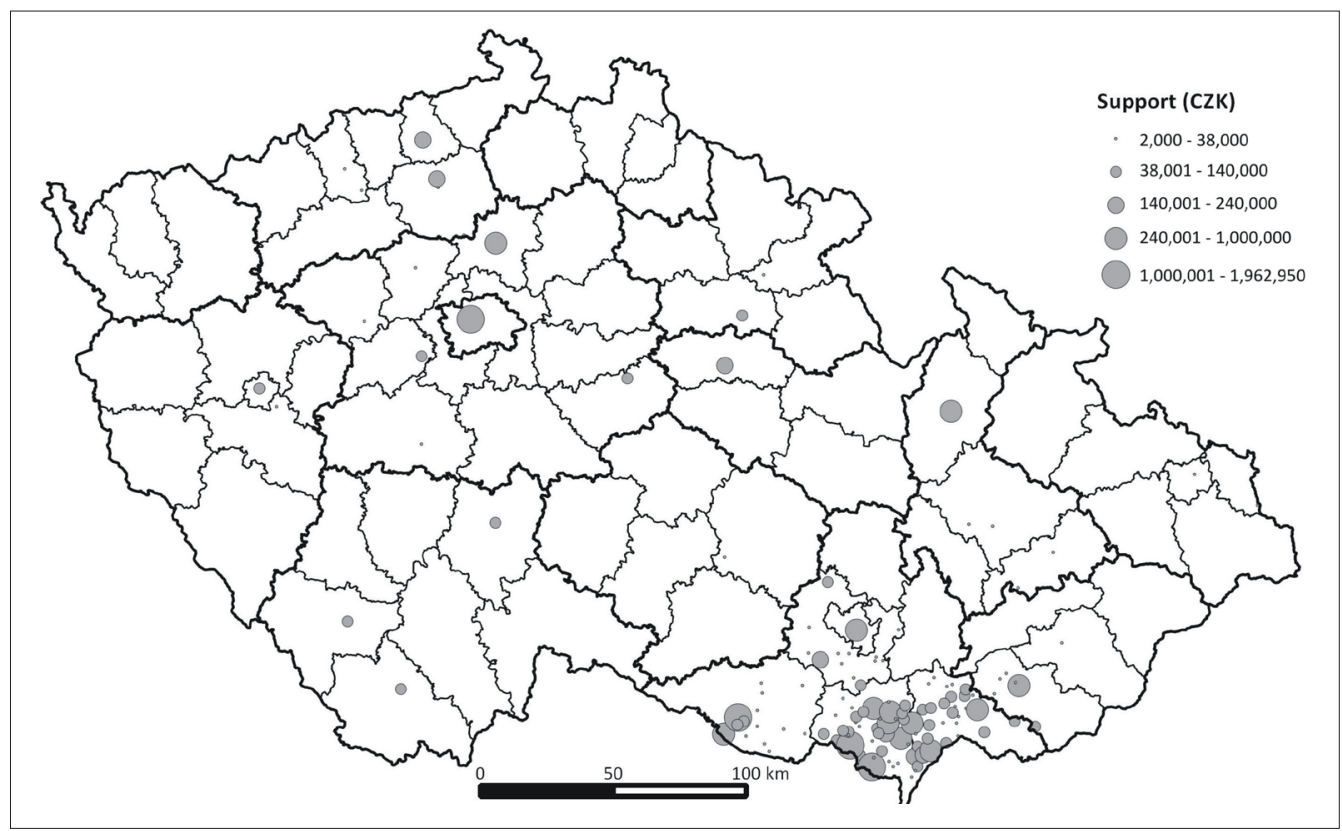

Fig. 4: Support of the Wine Growers Fund of the Czech Republic in 2013

Source: Wine Growers Fund of the Czech Republic, 2013

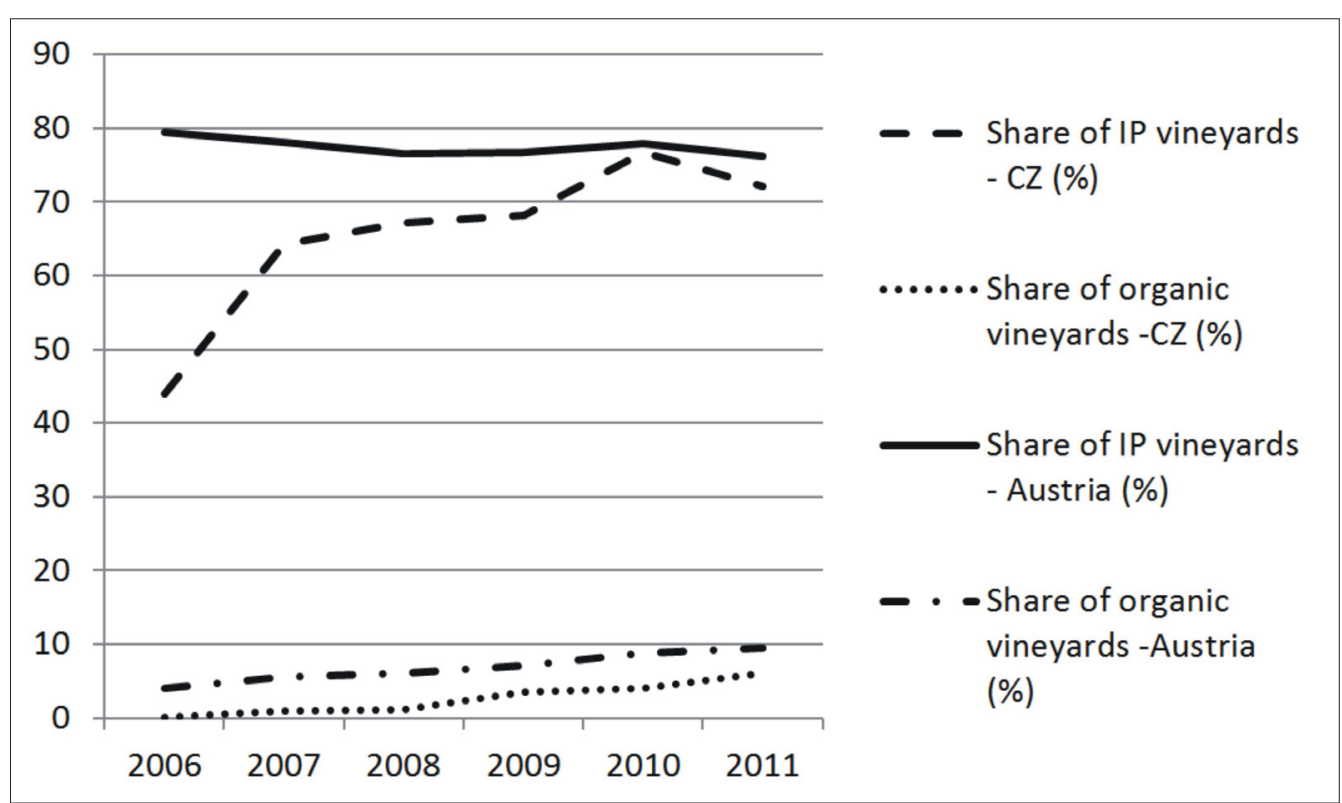

Fig. 5: The share of IP and organic vineyards in productive vineyards in Austria and in the Czech Republic (\%) Sources: MoA CR (2007a, 2008, 2009, 2010a, 2011, 2013a, 2013b); Bundesanstalt für Bergbauernfragen (2006, 2007, 2008, 2009, 2010, 2011) 
beneficiaries of direct payments, while businesses of natural persons gain subsidies rather exceptionally (they often maintain the position: "I don't want anything from anybody, so nobody can expect anything from me either"). Receiving direct payments for a very small area of farmland does not translate into a substantial income for the small vinegrowers. On the other hand, their approach often excludes them also from active participation in other financial means (e.g. from the European Agricultural Fund for Rural Development - EAFRD). Agri-environment schemes, co-financed by the EAFRD, have been used by numerous large firms for environmentally influenced ways of farming vineyards since 2004. Financial subventions for integrated vine production and for organic farming in vineyards have recently brought into being the most significant qualitative changes in vine growing in the Czech Republic (Fig. 5). The simple emphasis on quality production of grapes is typical for the majority of companies which also produce wine. Compared to the period before 1989, a reduction of grapes from one vine bush is evident for the majority of growers quality is preferred over quantity.

\subsection{Integrated production of vine}

Integrated production (IP) of vine is based on a relatively strict observation of principles defined by the International Organisation for Biological Control (IOBC). Integrated production is derived from the rules of sustainable development, which maintain the basic life needs for present and future generations, do not reduce biodiversity and, at the same time, preserve the natural functions of agri-ecosystems. According to Ekovín (a civic association, the only organization in the CR bringing together growers certified by IOBC), it is the way of farming which "struggles to achieve optimal yields of a higher quality in an environment-friendly way". The whole system approach to agriculture is typical for IP it is an approach applied to the whole business, and parallel conventional production is not allowed. In a similar fashion to organic farming, it has clearly-defined rules: a grower is obliged to use just a limited spectrum of pesticides; the number of fungicide applications is limited; and maximum doses of fertilizers are prescribed. There is an obligation to plant greenery in at least every second inter-row of a vineyard to reduce water erosion. Products from viticulture in the system of IP are grapes and subsequently wines labelled as "wines from integrated production".

Although the rules and principles of integrated production had been formulated in Switzerland in the 1970s and the technology for the biological protection of vineyards was developed and tested already in the former Czechoslovakia in co-operation with experts and farmers, IP saw a mass practical application in other countries earlier, e.g. in Austria (at the beginning of the 1990s), Germany and northern Italy. In the first half of the 1990s, the Association of Integrated Production of Grapes and Wines was created but the number of members grew only slowly at first (in 1999 it included 35 businesses mainly from the Břeclav and Hodonín districts). In 2004, vineyards in the IP system already covered an area of 5,837.7 ha. The environment-friendly approach of managing vineyards expanded to a greater degree only after 2005, when IP was subsidized for the first time.

In the period from 2007-2013, the integrated production of vine was a part of projects subsidized from the Rural Development Programme - agri-environmental measures (AEM). The subsidies led to a mass expansion of IP, mainly in larger businesses. Currently it is the most widely-used organically-oriented way of farming in vineyards - at the beginning of 2012, IP was applied on 11,535 ha, which means in about three-quarters of the productive vineyards in the Czech Republic. In terms of the proportion of IP implementation in the area of productive vineyards, this country has reached the level of Austria, where IP had been implemented on a large scale since the early 1990s. IP funding in Slovakia was delayed, but since 2007 it has been widely used $-24 \%$ of viticulturists from beneficiaries of direct payments at the same time implement IP on an area of 6,686 ha of vineyards - i.e. on approximately $63 \%$ of the area of productive vineyards (CCTIA as of 2011). In a similar way to the situation in the Czech Republic, some vine growers apply the methods with no claims of subsidy; it can be assumed, then, that the real area of vineyards managed in line with the ideas of IP is even higher. In Austria, thousands of growers have been using IP for many years (Tab. 3). In practice, integrated production is very often a precursor of a business transition towards organic viticulture, as many businesses have vineyards in IP and at the same time, they have a small area that is organically farmed. In such situations, the area of vineyards in IP has been slightly decreasing for several years "in favour of" the expanding area of vineyards farmed organically.

Moravian vine growers usually evaluate IP very positively, not only considering biodiversity and enhanced soil fertility, etc., but maintaining that villagers can benefit from it too. The countryside seems to be visibly enhanced aesthetically and water erosion is reduced in particular (roads are not covered with mud washed from vineyards after torrential rains as in the past, when the inter-rows were bare). Many vine growers do not consider the difference between IP and organic viticulture as significant. Some of them even prefer

\begin{tabular}{|l|c|c|c|c|c|c|c|c|}
\hline \multirow{2}{*}{} & \multicolumn{2}{|c|}{ Czech Republic } & \multicolumn{2}{|c|}{ Slovakia } & \multicolumn{2}{c|}{ Austria } & \multicolumn{2}{c|}{ Germany } \\
\cline { 2 - 11 } & 2005 & 2011 & 2005 & 2011 & 2005 & 2011 & 2005 & 2011 \\
\hline Vine growers in IP & 159 & $628^{1)}$ & $\mathrm{x}$ & 116 & 8,635 & 5,627 & $\mathrm{n} / \mathrm{a}$ & $\mathrm{n} / \mathrm{a}$ \\
\hline Area under vineyards in IP (ha) & 6,961 & 11,452 & $\mathrm{x}$ & 6,686 & 36,924 & 33,077 & 36,924 & 33,440 \\
\hline Vineyards in IP/ productive vineyards (\%) & 48.8 & 72.1 & $\mathrm{x}$ & 65.4 & 80.7 & 76.0 & 37.4 & $33.5^{2)}$ \\
\hline
\end{tabular}

Tab. 3: Implementation of the integrated vine production system in vineyards of the Czech Republic and neighbouring countries in 2005 and 2011

Notes: 1) Reference year 2010; 2) System of IP support in Germany differs from the CR: according to Hluchý (2012), IP is practised by $80-90 \%$ of vine growers in Germany; $x$ - Integrated production payments in Slovakia since 2007; n/a-data not available

Sources: MoA CR, 2007, 2013a; Bundesanstalt für Bergbauernfragen, 2011; CCTIA, 2013; Federal Statistical Office Germany, 2011; authors' calculations. 
IP from the ecological point of view because heavy machines causing soil compaction and disturbing the tranquillity of vineyards are used less frequently in comparison to organic farming, in which the machines have to travel to vineyards more often considering the character of applied substances. According to the experience of experts studying the influence of IP on biodiversity in vineyards over a long time period, it has to be admitted that the IP technology is formulated relatively broadly and that the countryside may but, at the same time, does not have to benefit from it (Hluchý, 2013).

\subsection{Organic viticulture}

Organic viticulture can be described as organic farming (specified in Act No. 242/2000 Coll.) in vineyards. It is a system of farming which tries to minimize damage to the environment (use of synthetic fertilizers and synthetic formulations for vine protection is not allowed). The product is organic grapes, which, if meeting technological conditions for organic food production (limiting the use of cultivated yeasts, enzymes and synthetic refining and stabilizing agents), can be used for organic wine production. Organic wine production has been regulated by European legislation only since 2012 ; before this date, wine makers could label the bottles with "made of grapes from organic production", but most of their production ended up as conventional wines.

In 2011, organic farming in vineyards was practised in 49 countries on a total area of 258.2 thousand hectares (FiblIFOAM Survey). By far most of the vineyards in the organic system are farmed in Europe (231.4 thousand hectares). Countries with the longest tradition of organic viticulture include Spain (79.0 thousand ha), France (61.1 thousand ha) and Italy (52.8 thousand ha). Non-European countries worth mentioning are the USA (11.4 thousand ha), Turkey (8.9 thousand ha) and Iran (5.7 thousand ha). Countries with a high proportion of organically farmed vineyards of the total area are Austria with its long tradition of organic farming (9.5\%), France (8.0\%), Spain (7.9\%), Italy $(7.3 \%)$, Jordan $(6.0 \%)$ and the Czech Republic (5.7\%). From a comparison of the development of the share of organic vineyards in the total area of vineyards registered, the Czech Republic can be categorized as one of the countries with the most rapid development, even at a global scale. Organic viticulture is developing rapidly also in Bulgaria, Croatia and Iran.

The first organically farmed vineyards started to appear in the Czech Republic as late as in the first half of the 1990s. There are several factors explaining the growing interest in this kind of farming. The change could have been influenced, for example, by the atypical and extremely rainy weather in 2010, which significantly influenced the quality of grapes as well as the incidence of fungal diseases. Final yields of organic vineyards were not so badly affected as compared to those conventionally farmed.

In 2011, the area of organically farmed vineyards in the Czech Republic was recorded at almost 1,000 ha (i.e. 5.6\% of productive vineyards) and subsidies for organic farming in vineyards were received by 100 companies (Tabs. 4 and 5), while there were still large differences among regions in practising organic viticulture (Fig. 6). Most entities with organic vineyards can be found in the Břeclav district, where the first companies were engaged in organic viticulture by the early 1990s (there are more than 50\% of all organic vine growers and organic vineyards in the Czech Republic in this district, with 513.1 ha under cultivation). In the Znojmo and Hodonín districts, there are respectively 10 companies farming 221.5 ha and 17 entrepreneurs farming $95.2 \mathrm{ha}$. In the vine region of Bohemia, more significant areas of vineyards in the system of organic farming can be found only in the district of Kutná Hora (3 subjects, 56.5 ha). Both numerous vine villages such as Velké Bílovice (5), Čejkovice (4) or Rakvice

\begin{tabular}{|l|c|c|c|c|c|c|c|c|}
\hline & \multicolumn{2}{|c|}{ Czech Republic } & \multicolumn{2}{c|}{ Slovakia } & \multicolumn{2}{c|}{ Austria } & \multicolumn{2}{c|}{ Germany } \\
\cline { 2 - 9 } & 2005 & 2011 & 2005 & 2011 & 2005 & 2011 & 2005 & 2011 \\
\hline Organic vine growers (number) & $4^{1)}$ & 100 & $\mathrm{n} / \mathrm{a}$ & 7 & 496 & 809 & 1,187 & $\mathrm{n} / \mathrm{a}$ \\
\hline Organic vineyards (ha) & 20 & 965 & $91^{2)}$ & 69 & 1,791 & 4,178 & 2,600 & 4,512 \\
\hline Organic farms (total) & 829 & 3,920 & 117 & 364 & 20,185 & 21,575 & 17,557 & 16,532 \\
\hline Organic area total (ha) & 254,982 & 482,927 & 53,091 & 180,260 & 479,817 & 536,877 & 782,475 & 980,851 \\
\hline
\end{tabular}

Tab. 4: Organic viticulture in the Czech Republic and in neighbouring countries in 2005 and 2011

Notes:1) Reference year 2006; 2) Data as of 31 March 2006; n/a-data not available

Sources: MoA CR, 2006, 2013b; CCTIA, 2013; Bundesanstalt für Bergbauernfragen, 2006, 2012; Federal Statistical Office, 2006, 2011; German Wine Institute, 2006, 2013

\begin{tabular}{|l|c|c|c|c|}
\hline & $\mathbf{2 0 0 8}$ & $\mathbf{2 0 0 9}$ & $\mathbf{2 0 1 0}$ & $\mathbf{2 0 1 1}$ \\
\hline Area of vineyards in OF (ha) - incl. areas in conversion & 450.2 & 645.1 & 802.8 & 965.1 \\
\hline Of these area of vineyards in OF - certified (ha) & 18.1 & 34.4 & 234.6 & 447.5 \\
\hline Number of entities with organic vineyards (total) & 40 & 65 & 83 & 100 \\
\hline Number of legal entities & 16 & 24 & 28 & 35 \\
\hline Number of natural persons & 24 & 41 & 55 & 65 \\
\hline $\begin{array}{l}\text { Area of vineyards under organic farming } \\
\text { operated by businesses of natural persons (ha) }\end{array}$ & 271.4 & 436.2 & 553.3 & 680.2 \\
\hline
\end{tabular}

Tab. 5: Development of organically farmed vineyards in the Czech Republic 2008-2011

Sources: MoA CR, 2013b; authors' calculations 


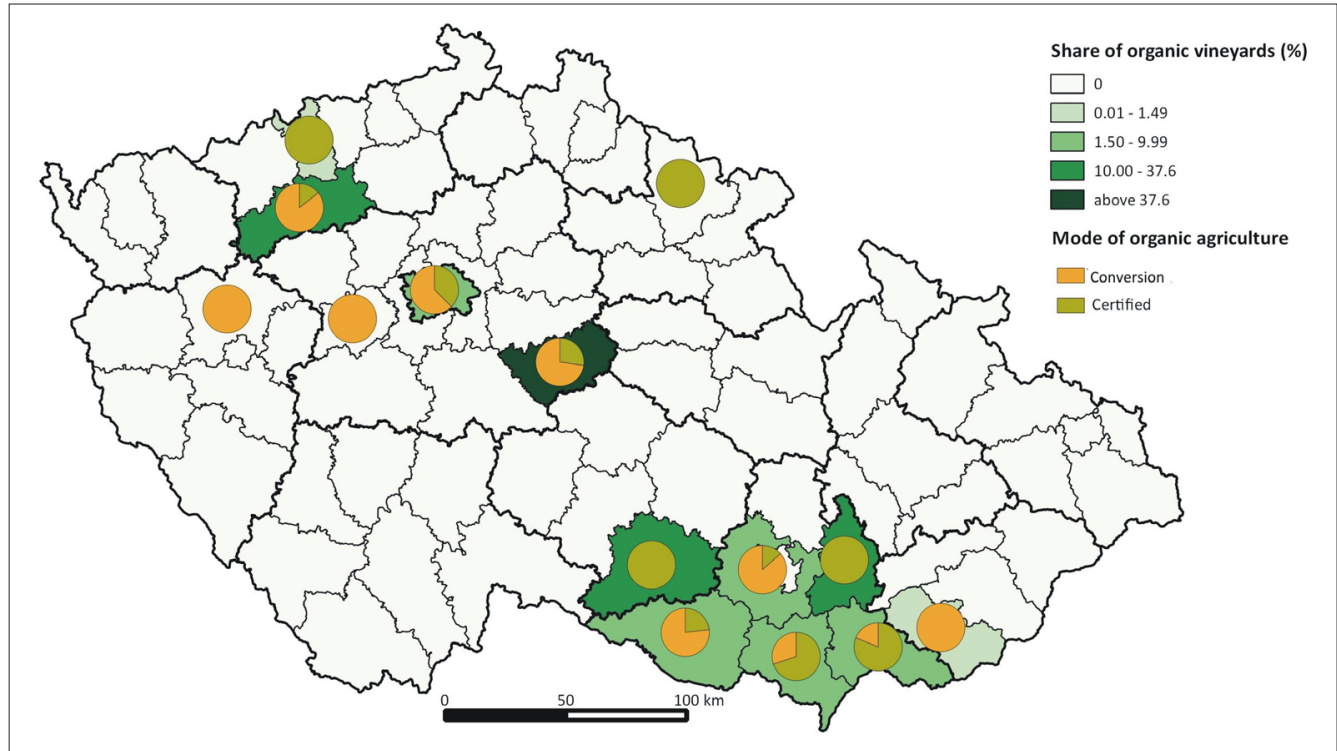

Fig. 6: Organic vineyards in the Czech Republic in 2012 Sources: CISTA, 2012, COSMC, 2012

(4), and the towns of Mikulov (8), Dolní Kounice (5), Bzenec (4) and Hustopeče (4) can be classified as municipalities with a higher number of organically farmed vineyards (according to places of the residence or places of business, with the number of entities in brackets).

Regarding the proportion of vineyards, which have been already farmed organically, the district of Kutná Hora (37.6\%) comes first in the Czech Republic. In general, high proportions of organic farming (more than 10\% as opposed to the average of 5.6\% in 2011) occur only in districts with a very small total area of vineyards, which means that a single entity can drastically influence the average for that district ( Vyškov, Třebíč and Louny (CISTA, 2012)).

Smaller entities of up to 2 ha predominate in the structure of organically farming vine growers (almost onehalf of all growers). The average area of 9.6 ha of vineyard organically farmed (OF; including the areas in conversion) in 2011 was not reached by even one-quarter of growers. The six largest growers in the districts of Znojmo, Břeclav and Kutná Hora farm one-half of all organic vineyards in the Czech Republic.

Although many large Czech wine producers (many of which belong in the group of the largest grape growers, some of them farming vineyards with more than $400 \mathrm{ha}$ ), such as Vinium a.s. Velké Pavlovice, Vinofrukt a.s. Dolní Bojanovice, Patria a.s. Kobylí or Habánské sklepy s.r.o. Velké Bílovice, have been farming under the integrated production system at this time, some large producers already rely on the popularity of organic wines in the coming years and farm a part of their vineyards organically. These are for example Vinné sklepy Valtice a.s., Chateau Bzenec s.r.o. (daughter company of Bohemia Sect a.s. Starý Plzenec), Vinselekt Michlovský a.s., or the wine cooperative Templářské sklepy Čejkovice.

As in the system of integrated production, we can find some smaller vine growers who have been farming organically without claiming subsidies (there are not many such growers, although vine is considered one of the most demanding crops with respect to its protection against diseases and pests). We can mention, for example, viticulturists from the association of Autentists (bringing together small vine growers from various villages in the districts of Břeclav and Hodonín), who farm their vineyards organically under conditions stricter than the rules for organic wine production. They do not add sugar to wines, and in their own words, they let "the spirit of the place where the vine originated" excel in natural processes, so that the resulting wines would reflect the "terroir" as much as possible.

\section{Conclusions}

Some processes currently underway in Czech viticulture are similar to those in a number of European countries: there is a slow reduction in the total number of vine growers in the Czech environment, but the area of productive vineyards remains relatively stable. At the same time, some previously small growers have "legalized" their businesses and some former smaller family wineries are setting up new limited companies, creating websites allowing them to sell wine through the Internet, and starting to organize themselves in vine growers associations, participating actively in wine exhibitions, cultural events, etc. Most companies have adopted a strategy of enhancing the quality of produced wines and since quality, in general, is very hard to prove, an indirect proof of quality can be the growing number of international awards for Czech wine makers.

Enterprises that were earlier concentrated only on the import of cheap grapes or grape juice and subsequent wine production, have started to realize that for their own production quality raw materials are a necessity. The orientation to environmentally-beneficial ways of viticulture closely connects with these general trends - quality grapes reflecting the genius loci of a particular place can be produced, according to vine growers' opinion, in healthy vineyards not loaded with chemicals. Growing in the IP system or in the system of organic farming can bring, apart from the expected favourable effects in the field of environment protection, economic benefits in the future as well. Generally, it is supposed that, based on the increasing consumption of organic products in developed Western European countries (Switzerland, Germany, etc.), these changes will benefit the producers in economic terms. On the other hand, it is evident that estimating market development for a period longer than three years (conversion period for perennial crops in organic farming) is very difficult. 
Czech viticulture has undergone a great change in the last five years - large, conventionally- farmed vineyards can hardly be seen any more in the Czech Republic. Most vineyards are farmed under the system of integrated production, and especially in Moravia the areas of organic vineyards are rapidly expanding. As to the share of vineyards in IP, the country compares favourably with Austria. The total extent of organic viticulture, however, still differs from Austria, considering both the number of growers and the total area of vineyards. On the other hand, it has not been a marginal issue compared to Slovakia. It can be concluded that general awareness of these alternative ways of farming is increasing among farmers, and that growers are gaining experience and that consumers can taste completely new products and technologically-demanding specialities, such as organic sparkling wines or organic straw wines of local origin. The trends of greening viticulture in the Czech Republic can be seen as still copying the tendencies in developed western European countries, but it can be assumed that some organically farming entities will also focus on biodynamical viticulture in the future.

\section{References:}

BANKS, G., OVERTON, J. (2010): Old World, New World, Third World? Reconceptualising the Worlds of Wine. Journal of Wine Research. Vol. 21, No. 1, p. 57-75.

BARHAM, E. (2003): Translating terrior: the global challenge of French AOC labelling. Journal of Rural Studies. Vol. 19, No. 1, p. 127-138.

BARKER, J., LEWIS, N., MORAN, W. (2001): Reregulation and the development of the New Zealand wine industry. Journal of Wine Research, Vol. 12, No. 3, p. 199-221.

BÖLW (2011): Zahlen, Daten, Fakten: Die Bio-Branche 2011. Berlin, Bund Ökologische Lebensmittelwirtschaft. 36 pp.

Bundesanstalt für Bergbauernfragen (2006, 2007, 2008, 2009, 2010, 2011): Grüner Bericht 2007, 2008, 2009, 2010, 2011, 2012 [online]. Bundesanstalt für Bergbauernfragen [cit. 10.10.2013]. Avalaible at: URL: http://www.gruenerbericht.at

CCTIA (2013): Údaje o počtech pěstitelů vinné révy $\mathrm{z}$ vinohradnického registru ÚKSÚP a počtech přijemců dotací na Integrovanou produkci révy vinné z Programu rozvoje venkova $\mathrm{v}$ r. 2011. Interní data ÚKSÚP poskytnuté k 30. 9. 2013.

CISTA (2012): Vinná réva - plodící vinohrady. ÚKZUZ/ ORV_20121102_data k 30. 7. 2012, ÚKZUZ, 5 pp.

CISTA (2013): Výměra jednotlivých zemědělských kultur v EZ/PO za kraje a okresy dle LPIS k 27. 9. 2013. ÚKZUZ, $10 \mathrm{pp}$.

COSMC (2013): Souhrnné přehledy o půdním fondu z údajů katastru nemovitostí České republiky. Praha, Czech Office for Surveying, Mapping and Cadastre, 84 pp.

CHARTERS, S. (2006): Wine and Society: The Social and Cultural Context of a Drink. Oxford, Elsevier Butterworth-Heinemann. $358 \mathrm{pp}$.

CHLÁDKOVÁ, H., POŠVÁR, Z., ŽUFAN, P. (2004): Consumer habits in the Czech wine market. Agricultural Economocs. Vol. 50, No. 9, p. 323-330.

CHLÁDKOVÁ, H., TOMŠíK, P., GURSKÁ, S. (2009): The development of main factors of the wine demand. Agricultural Economics. Vol. 55, No. 7, p. 321-326.
CSO (2009): Vineyards survey 2009 [online]. CSO [cit. 21.09.2013]. Avalaible at: URL: http://www.czso.cz/ csu/2011edicniplan.nsf/engpubl/2135-11-eng_n_2011

DOUGHERTY, P. H. [eds.] (2012): The Geography of Wine: Regions, Terroir and Techniques. Springer. $255 \mathrm{pp}$.

GADE, D. W. (2004): Tradition, Territory and Terroir in French viniculture. Annals of the Association of American Geographers. Vol. 94, No. 4, p. 848-867.

German WineInstitute (2006, 2013): Deutscher Wein Statistik 2005/2006, 2012/2013 [online]. DWI [cit. 18.09.2013]. Available at: URL: http://www.deutscheweine.de

GWYNNE, R. N. (2008): Value chains and the geographies of wine production and consumption. The Geographical Journal. Vol. 174, No. 2, p. 95-96.

European Commision (2010): An Analysis of the EU organic sector. European Commision Deirectorate General Agriculture and Rural Development. 92 pp.

Federal Statistical Office (2010): Agrarstrukturen in Deutschland [online]. Statistisches Bundesamt [cit. 12.09.2013]. Avalaible at: URL: https://www.destatis. de/DE/Publikationen/Thematisch/LandForstwirtschaft/ Landwirtschaftzaehlung/AgrarstruktureninDeutschland. html;jsessionid=7B214DCBEB8C6B40305881B192F842A2. cae2

Federal Statistical Office (2011): Betriebe mit Weinbau. Landwirtschaftszahlung/Agrarstrukturerhebung [online]. Statistisches Bundesamt [cit. 18.09.2013]. Avalaible at: URL: https://www.destatis.de/DE/ Publikationen/Thematisch/LandForstwirtschaft/ Landwirtschaftzaehlung/BetriebeWeinbau2030223109004. pdf;jsessionid=8038BAA3D4F3F28D45743BBAF1EDB74A. cae2?_blob=publicationFile

FiBL (2013): Data sources and data providers of the FiBLIFOAM surfy [online].FiBL[cit. 23.09.2013]. Avalaible at: URL: http://www.organic-world.net/statistics-datasources.html

GRAFFE, L. (1984): Pěstování vinné révy v českých zemích. Sborník referátů k XVI. sjezdu ČSGS. Brno, GGÚ ČSAV, 1984, p. 294-299.

HICL, Z. (2012): Evaluation of viniculture in the Czech Republic from the perspective of industry and prediction of development until 2020 according to selected variables. Acta Universitatis Agriculturae et Silviculturae Mendelianae Brunensis, Vol. 60, No. 7, p. 89-100.

HLUCHÝ, M. (2008): Rizika konvenčního vinohradnictví pro biodiverzitu krajiny. In: Šarapatka, B., Niggli, U.: Zemědělství a krajina. Cesty k vzájemnému souladu. Olomouc, Palacký University.

HLUCHÝ, M. (2011): Ekologické vinohradnictví u nás. Zemědělec, Vol. 2011, No. 23, p. 27.

HLUCHÝ, M. (2012): Analýza možností dotací Integrované produkce révy vinné po zavedení integrované ochrany rostlin jako standardního systému ochrany rostlin v zemědělství České republiky. Ekovín o. s., 95 pp.

HLUCHÝ, M. (2013): Z outsidera lídři evropského ekologického vinařství. Veronica, Vol. 2013, No. 1, p. 1-4.

Statistisches Bundesamt: Destatis [online]. Statistisches Bundesamt [cit. 12. 9. 2013]. Avalaible at: URL: https:// www.destatis.de/DE/Startseite.html 
HRABALOVÁ, A., HANDLOVÁ, J., WOLLMUTHOVÁ P. (2007): Vývoj ekologického zemědělství v zemích střední a východní Evropy v letech 1997 až 2004. Bulletin VÚZE, Vol. 2007, No. 4, p. 31.

IAEI (2012): Statistická šetření ekologického zemědělství základní statistické údaje (2011). ÚZEI, Brno, 54 pp.

JONES, A. (2003): Power in Place: Viticulture spatialities of globalization and community empowerment in the Languedoc. Transactions of the Institute of British Geographers. Vol. 27, p. 11-29.

JUNG, I. (1984): Ekonomické podmienky rentabilnej výroby hrozna v ČSSR. Zemědělská ekonomika, Vol. 30, No. 3 , p. $165-174$.

KORÁB, P. (2012): European wine policy and perceptions of Moravian winemakers. A pilot study in the Czech Republic. Acta Universitatis Agriculturae et Silviculturae Mendelianae Brunensis, Vol. 60, No. 4, p. 207-214.

KRAUS,V. (1999): Réva a víno v Čechách a na Moravě. Praha, Radix, 1999, 286 pp.

KRAUS, V., KOPEČEK, J. (2006): Setkání s vínem. Praha, RADIX s.r.o., 158 pp.

KUČEROVÁ, R. (2005): Factors of wine demand in the Czech Republic and in the neighbouring wine countries. Agricultural Economics, Vol. 51, No. 8, p. 403-410.

MARKS, D. (2011): Competitiveness and the Market for Central and Eastern European Wines: A Cultural Good in the Global Wine Market. Journal of Wine Research, Vol. 22, No. 3, p. 245-263.

MoA CR (2006, 2007a, 2008, 2009, 2010a, 2011, 2012): Zelená zpráva 2005, 2006, 2007, 2008, 2009, 2010, 2011. [online]. MoA CR [cit. 26.09.2013]. Available at: URL: http:/eagri.cz/public/web/mze/ministerstvo-zemedelstvi/ vyrocni-a-hodnotici-zpravy/zpravy-o-stavu-zemedelstvi/

MoA CR (2007b, 2010b, 2013a): Situační a výhledová zpráva réva vinná a víno 2006, 2009, 2012. MoA CR [cit. 03.10.2013].Available at: URL: http://eagri.cz/public/ web/mze/zemedelstvi/publikace-a-dokumenty/situacni-avyhledove-zpravy/rostlinne-komodity/reva-vinna-a-vino/

MoA CR (2013b): Seznam ekologických zemědělců 2008-2011 [online]. MoA CR [cit. 21.09.2013]. Avalaible at: URL: http://eagri.cz/public/web/mze/zemedelstvi/ekologickezemedelstvi/seznamy-podnikatelu/seznam-ekologickychzemedelcu

OVERTON, J., MURRAY, W. E., BANKS, G. (2012): The race to the bottom of the glass? Wine, geography and globalisation. Globalization. Vol. 9, No. 2, p. 273-287.

OVERTON, J., MURRAY, W. E., SILVA, F. P. (2011): The remaking of Casablanca: the sources and impacts of rapid local transformation in Chile's wine industry. Journal of Wine Research. Vol. 23, No. 1, p. 47-59.

PONT, P. M. (2011): Who Grows the Grapes? The Changing Relationship of Quality in Argentine Wine Production. Journal of Wine Research. Vol. 22, No. 1, p. 1-17.

ROZBORILOVÁ, E. (2012): Farm Structure Census 2010 Complex Results [online]. SOSR [cit. 23.09.2013]. Avalaible at: URL:http://portal.statistics.sk/files/Sekcie/ sek_500/polnohospodarstvo/publikacie-stiahnutie/fss/ fsc-2010-komplexne-vysledky_sk_en.pdf.
SCHMIDT, M. [ed.]. (2008): Statistisches Jahrbuch über Ernährung Landwirtschaft und Forsten der Bundesrepublik Deutschland 2008. Bremerhaven, Wirtschaftsverlag NW GmbH, 2008, 576 pp.

ŠKORPÍKOVÁ, A. (2002): Factor conditions of the viticulture and wine sector in the EU member states, in the Czech Republic and in the selected candidate countries. Agricultural Economics.Vol. 48., No. 7, p. 303-310.

Statistics Austria (2009): Basic survey of areas under vine 2009 [online]. Statistics Austria [cit. 23.09.2013]. Avalaible at: URL: https:/www.statistik.at/web_en/ statistics/agriculture_and_forestry/farm_structure cultivated area yields/wine/index.html\#index1

STOLZ, H., SCHMID, O. (2008): Consumer attitudes and expectations of organic wine. In: Organic wine and viticulture conference, Levizzano near Modena, Italy, June 18-20, 2008.

ŠKORPÍKOVÁ, A., ČERNÍKOVÁ, R.: Bargaining Power of Suppliers in the Vine-growing and Wine Production Sector in the Czech Republic [online]. Agris [cit. 16.09.2013]. Avalaible at: URL: http://www.agris.cz/ Content/files/main_files/61/139147/skorpik.pdf

The National Wine Centre (2013): Wine of Czech Republic [online]. The National Wine Centre [cit. 05.10.2013]. Avalaible at: URL: http://wineofczechrepublic.cz

TOMŠÍK, P., CHLÁDKOVÁ, H. (2005): Comparison of analyse sof Winegrowing and Wine-production in the Czech Republic, EU, and South Africa. Agricultural Economics, Vol. 51., No. 7, p. 322-328.

TOMŠÍK, P., SEDLO, J. (2005): Adaptation of the Czech viniculture to the conditions of European Union. Agricultural Economics, Vol. 51, No. 11, p. 509-520.

TOMŠÍK, P., SEDLO, J. (2006): Přizpůsobování odvětví vinohradnickovinařského České republiky na podmínky Evropské unie. In: Medzinárodné vedecké dni 2006. Nitra, SPU Nitra, p. 10-23.

TOMŠÍK, P., ŽUFAN, P., SEDLO, J. (2006): Atraktivita odvětví vinohradnictví a vinařství v České republice ve fázi adaptace na jednotný trh Evropské unie. Acta Universitatis Agriculturae et Silviculturae Mendelianae Brunensis, Vol. 54, No. 3, p. 101-113.

VAUDOUR, E. (2002): The Quality of Grapes and Wine in Relation to Geography: Notions of Terroit at Various Scales. Journal of Wine Research. Vol. 13, No. 2, p. $117-141$.

WILLER, H. (2008): Organic Viticulture in Europe: Development and current statistics. In: Organic wine and viticulture conference, Levizzano near Modena, Italy, June 16 and 17, 2008.

Wine Fund CR (2013): Přehled přijatých žádostí dle ust. § 2 odst. 2 vyhlášky č. 97/2006 Sb. v roce 2013, v termínech od 1. 1. do 15. 2. a od 1. 7. do 15. 8. 2013. 2 pp.

ŽUFAN, P. (2004a): Změnotvorné síly v odvětví vinohradnictví a vinařství v České republice. In: Medzinárodné vedecké dni 2004. Nitra, SPU Nitra, p. 1244-1249.

ŽUFAN, P. (2004b): Czech wine-production industry and recent movement forces. Agricultural Economics, Vol. 50, No. 9, p. 400-404. 


\section{Authors' addresses:}

Mgr. Ilona SVOBODOVÁ, e-mail: ilona.svobodova@gmail.com

Assoc. Prof. RNDr. Antonín VĚŽNÍK, CSc, e-mail: veznik@sci.muni.cz

Mgr. Michael KRÁL, e-mail: michael.kral@mail.muni.cz

Institute of Geography, Faculty of Science, Masaryk University

Kotlářská 2, 61137 Brno, Czech Republic

Initial submission 29 October 2013, final acceptance 10 February 2014

Please cite this article as:

SVOBODOVÁ, I., VĚŽNÍK, A., KRÁL, M. (2014): Viticulture in the Czech Republic: Some spatio-temporal trends. Moravian Geographical Reports, Vol. 22, No. 1, p. 2-14. DOI: 10.2478/mgr-2014-0001. 